\title{
Properties of I Shaped Paver Blocks Using fly Ash Based Geopolymer Concrete
}

\author{
Dr.R.Kumutha ${ }^{1}$, A. Aswini ${ }^{2}$, M.Ellakkiya ${ }^{2}$, T.Karthika ${ }^{2}$ and Dr.K.Vijai ${ }^{3}$ \\ ${ }^{I}$ Dean \& Professor, Department of Civil Engg., Sethu Institute of Technology, Kariapatti- 626115,TN, India \\ ${ }^{2}$ Undergraduate Students, Department of Civil Engg.,Sethu Institute of Technology, Kariapatti- 626115,TN, \\ India \\ ${ }^{3}$ Professor\& PG Head, Department of Civil Engg., Sethu Institute of Technology, Kariapatti- 626115,TN, India
}

\begin{abstract}
The living planet earth has encountered global warming due to various issues. One of the main reasons is construction industries since the foremost component of concrete is cement, which has its own environmental problems. The cement industry is one of the prime producers of carbon-di-oxide. It is estimated that about 7\% of greenhouse i.e. Carbon-di-oxide gas is being emitted into atmosphere on account of production of OPC alone at global level. On other hand disposal of solid waste is a major problem. Coal power plants produce solid waste called fly ash whose disposal is difficult. Therefore urgent changes are required relating to emissions, production and application of sustainable and eco-friendly materials. This led to concept of geopolymer concrete by which cement can be entirely avoided in the concrete. This paper aims to develop geo-polymer paver blocks. The paver blocks developed are tested for their compressive, split tensile, flexural and abrasive strength as per Indian Standards 15658:2006.
\end{abstract}

Keywords: Abrasive strength, Flexural strength, Geopolymer, Paver block, , Split tensile strength

\section{Introduction}

Paver block has been used in construction for about thousands of years. Paver block is nothing but an unreinforced solid block appropriate for outdoor applications. The first concrete pavers were shaped just like a brick, 4" $\times 8$ " $(10 \mathrm{~cm} \times 20 \mathrm{~cm})$ and they were called Holland Stones. These units turned out to be cheap to produce and were exceptionally strong. In addition to being economical, interlocking concrete pavers are also broadly obtainable in water-permeable designs, which have additional ecological benefits. These paver blocks allowed water to drain through their interlocks and prevent soil erosion or increase water level in the neighboring land area. Production of ordinary Portland cement had resulted in emission of greenhouse gas i.e. Carbon-di-oxide. As of 2010 the world production of OPC was 3300 million tons annually. This accounts for $5 \%$ of man-made emission of carbon-di-oxide at global level. On other hand clearance of solid waste is a major problem. Coal power plants produce solid waste called fly ash whose disposal is difficult. As the intricacy of environmental issues and solid waste management increases day by day it has become essential to develop sustainable and eco-friendly materials. This led us to develop geopolymer paver blocks for medium traffic with thickness of $80 \mathrm{~mm}$. I-shaped paver blocks were produced and tested for their properties. Geopolymers involves the activation of fly ash by alkaline solution which does not require water for curing.

Ling,T.C et al [2010] investigated the long term strength of rubberized concrete paving blocks (RCPB). The effect of three curing conditions on compressive strength was studied. Additional strength tests which included flexural and splitting tensile strength were conducted to determine the strength characteristics and to enhance the understanding of the RCPB properties. Four batches of RCPB that replaced sand volume with crumb rubber at $0 \%, 10 \%, 20 \%$ and $30 \%$ were produced in a commercial plant. As the rubber content exceeded $20 \%$, RCPB would cause a great reduction in strength although ductility increases greatly. Thus, this would be beneficial for trafficked pavement. Aaron Darius Vaz1 et al [2012] concluded by their experimental investigation that geopolymer concrete can be effectively used for the manufacturing of precast concrete paver blocks. Geopolymer Concrete (GPC) paver blocks have high compressive strength for the same mix proportion and have high strength to gain ratios. GPC paver blocks outperform Ordinary Portland Cement (OPC) paver blocks under freezing and thawing conditions. This makes them suitable for cold environments where OPC based products get worse quickly.

Basil Mali, M. and Renjan Abraham [2016] concluded that geopolymer concrete is an excellent alternative to Portland cement concrete. Low calcium fly ash based Geopolymer concrete pavers have excellent compressive strength within short period (3days) and are suitable for practical applications.

Navya.G and Venkateswara Rao.J [2014] investigated the effect of polyester fibres on the compressive strength, water absorption and flexural strength of concrete paver blocks. Banupriya, C. et al [2016] investigated the use of quarry dust by replacing with river sand for making geopolymer bricks and paver blocks. Investigations were done on usage of eco-friendly. The geopolymer concrete specimens were tested for 
compressive strength, split tensile strength and flexural strength. Geopolymer bricks using 65\% FA \& 35\% GGBS produced good compressive strength. K. Vijai et al [2010] presented the results of an experimental study on the density and compressive strength of geopolymer concrete. The experiments were conducted on fly ash based geopolymer concrete by varying the types of curing namely ambient curing and hot curing. The ratio of alkaline liquid to fly ash was fixed as 0.4 . For all the samples the rest period was kept as 5 days. For hot curing, the temperature was maintained at $60^{\circ} \mathrm{C}$ for $24 \mathrm{~h}$ in hot air oven. The compressive strength test was conducted for each sample and the results showed that there is an increase in compressive strength with the increase in age for ambient cured specimens. For hot cured samples the increase in compressive strength with age was very less as compared to that of specimens subjected to ambient curing.

Girawale, M. S. [2015] studied the various properties of the geopolymer concrete and comparison was made with the OPC concrete. The compressive, flexural, split tensile strength of Geopolymer concrete were determined and it was found that, the strength basically depends on the variation of different parameters such as the ratio of $\left(\mathrm{Na}_{2} \mathrm{SiO}_{3} / \mathrm{NaOH}\right)$, molarity of the alkaline solution by keeping constant curing temperature constant of $800^{\circ} \mathrm{C}$. Srinivas, K. S.et al [2015] determined the compressive strength of geopolymer concrete subjected to acidic conditions and compared with Conventional Concrete (CC) performance under the same acidic conditions. Both GPC and CC shows reduction in compressive strength upon immersion in 5\% acidic solutions containing $\mathrm{H}_{2} \mathrm{SO}_{4}$ and $\mathrm{MgSO}_{4}$. However, significant reduction in strength occurred for conventional concrete which is an indication of better performance of GPC under acidic environment.

In the present investigation eco-friendly paver blocks having better interlocking effect were developed without cement using geopolymer technology that are suitable for heavy traffic conditions

\subsection{Materials used}

\section{Experimental Program}

Fly Ash: Fly ash is extracted from pulverized or crushed coal by suitable process such as by cyclone separation or electrostatic precipitation. Fly ash collected at later stages of electrostatic precipitator is finer than the fly ash collected at initial stages of electrostatic precipitator. The specific gravity of fly ash is given as 2.81.The chemical composition of fly ash is given in Table 1.

Ground Granulated Blast Furnace Slag: Ground granulated blast furnace slag (GGBS) is obtained by quenching molten iron slag from a blast furnace in water or steam, to produce a glassy, granular product that is then dried and ground into a fine powder. The specific gravity of GGBS is found to be 3.1. The chemical composition of GGBS is given in Table 2.

Alkaline Solution: A combination of sodium hydroxide and sodium silicate is taken as alkaline solution. The sodium hydroxide $(\mathrm{NaOH})$ solids of commercial grade in form of flakes were used. For the experimental investigation, $\mathrm{NaOH}$ solution with a concentration of $4 \mathrm{M}$ is considered which is prepared by dissolving 160 grams of $\mathrm{NaOH}$ solids in water and made up to one liter since 40 is the molecular weight of $\mathrm{NaOH}$.

Aggregates: Fine aggregate is basically sand obtained from the land or the marine environment. Fine aggregates generally consist of natural sand or crushed stone. As per IS 383-1970, fine aggregate are aggregates which passes through 4.75-mm IS sieve and coarse aggregate are aggregates most of which are retained in $4.75-\mathrm{mm}$ IS sieve. The physical properties of aggregates are given in Table 3. The fine aggregates confirms to Zone II. Coarse aggregates used are sound and free of soft or honeycombed particles.

Super plasticizers: Super plasticizers are also known as high range water reducers. Conplast SP430 which is based on sulphonated napthalene Polymers is supplied as a brown liquid and it is instantly dispersible in water. Conplast SP430 has been specially formulated to give high water reduction upto $25 \%$ without loss in workability or to produce high quality concrete of reduced permeability. The quantity of super plasticizer added in concrete is $3 \%$ by weight of cementitious materials.

Water: Water that is clean and free from injurious amounts of oils, acids, alkalis, salt, sugar, organic materials or other substances that may be deleterious to concrete is used. Extra water is added to improve the workability and the amount of water added is $10 \%$ by weight of binder materials (fly ash and GGBS).

Table 1: Chemical composition of fly ash

\begin{tabular}{|l|l|l|l|}
\hline S.No. & Oxides & $\begin{array}{l}\text { Requirements as per IS } \\
\mathbf{3 8 1 2 - 2 0 0 3} \\
(\% \text { by Mass })\end{array}$ & $\begin{array}{l}\text { Test result } \\
(\% \text { by Mass })\end{array}$ \\
\hline 1. & $\mathrm{SiO}_{2}+\mathrm{Al}_{2} \mathrm{O}_{3}+\mathrm{Fe}_{2} \mathrm{O}_{3}$ & Total $>70.0$ & 88.86 \\
\hline 2. & $\mathrm{CaO}$ & $<5.0$ & 0.5 \\
\hline 3. & $\mathrm{SiO}_{2}$ & $>35.0$ & 53.66 \\
\hline 4. & $\mathrm{MgO}_{3}$ & $<5.0$ & 2.89 \\
\hline 5. & $\mathrm{SO}_{3}$ & $<5.0$ & 0.35 \\
\hline 6. & $\mathrm{Na}_{2} \mathrm{O}$ of ignition & -- & 0.36 \\
\hline 7. & $\begin{array}{l}\text { Loss including moisture } \\
\text { incio }\end{array}$ & 1.02 \\
\hline
\end{tabular}


Table 2: Chemical composition of GGBS

\begin{tabular}{|l|l|l|l|}
\hline S.No. & Characteristics & $\begin{array}{l}\text { Requirements as per } \\
\text { BS:6699 }(\% \text { by Mass })\end{array}$ & Test result $(\%$ by Mass $)$ \\
\hline 1. & Loss on ignition & $<3.0$ & 0.29 \\
\hline 2. & Insoluble Residue & $<1.5$ & 0.4 \\
\hline 3. & Magnesia Content & $<14.0$ & 7.86 \\
\hline 4. & Sulphide Sulphur & $<2.0$ & 0.5 \\
\hline 5. & Sulphite Content & $<2.5$ & 0.4 \\
\hline 6. & Glass content & $>67.0$ & 93 \\
\hline 7. & Moisture & $<1.0$ & 0.1 \\
\hline 8. & Chloride content & $<0.1$ & 0.008 \\
\hline 9. & Manganese & $<2.0$ & 0.11 \\
\hline & Chemical Moduli & $>66.66$ & 77.46 \\
10. & $\mathrm{CaO}+\mathrm{MgO}^{2} \mathrm{SiO}_{2}$ & $>1.0$ & 1.37 \\
& $\mathrm{CaO}+\mathrm{MgO} / \mathrm{SiO}_{2}$ & $<1.4$ & 1.13 \\
\hline
\end{tabular}

Table 3: Physical properties of aggregates

\begin{tabular}{|l|l|l|l|}
\hline S.No. & Property & Fine aggregate & $\begin{array}{l}\text { Coarse } \\
\text { aggregate }\end{array}$ \\
\hline 1. & Specific gravity & 2.51 & 2.83 \\
\hline 2. & Fineness modulus & 2.87 & 7.55 \\
\hline
\end{tabular}

\subsection{Geopolymer concrete mix design for paver blocks}

The mix design process of geopolymer concrete was started by assuming the density of concrete as $2400 \mathrm{~kg} / \mathrm{m}^{3}$ out of which the quantity of aggregates was fixed as 77\%. The fine aggregates were taken as $30 \%$ of the total aggregates. Then by assuming alkaline liquid to binder ratio as 0.4 and sodium silicate to sodium hydroxide ratio as 2.5 , the proportions of various ingredients were arrived at. Here the binder consists of fly ash and GGBS. The mix consists of $30 \%$ GGBS out of the total binder content. The details of mix proportions are shown in Fig.1.

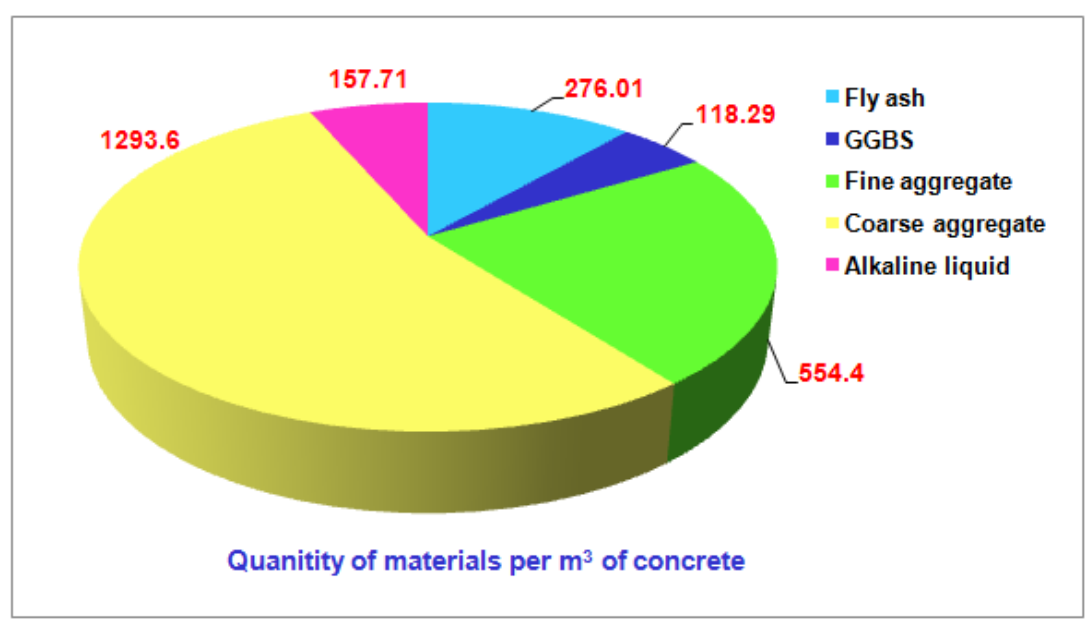

Fig.1. Mix proportions per cubic metre of concrete

\subsection{Specimens and tests procedure}

The paver block chosen for the present investigation is I - shaped paver block having a dimension of $215 \times 175 \times 60 \mathrm{~mm}$. The aspect ratio of the block is the ratio between the Length (L) to the Thickness $(\mathrm{T})$ of the block (L/T). As per IS 15658: 2006, minimum and maximum block thickness shall be 50mm and 120mm respectively and the maximum aspect ratio of the block is 4 .For the block considered in the present study, the aspect ratio is 3.58 which is within the limit of 4 . About 20 paver block samples were prepared as shown in Fig. 2 in order to determine various properties such as density, compressive strength, split tensile strength, flexural strength, water absorption and abrasion resistance. 


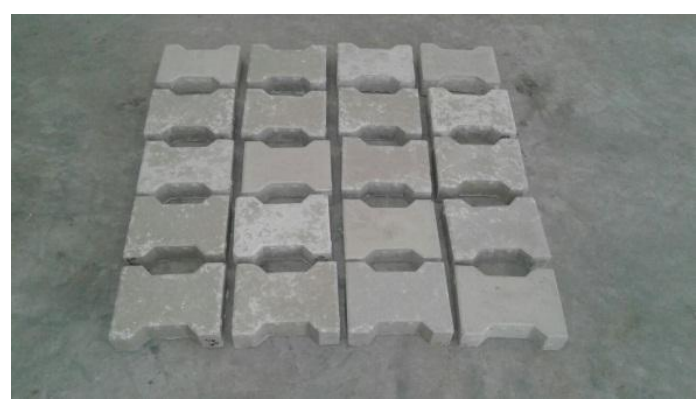

Fig.2. Paver blocks ready for test

The dimensions and plan areas of the specimens have been determined as per IS 15658: 2006. Density of the paver blocks were determined by dividing the mass of the block in $\mathrm{kg}$ to the volume of the block in $\mathrm{m}^{3}$.The compressive strength of paver block is found out using Compression Testing Machine as shown in Fig.3 by applying load without shock and the load is increased continuously at a rate of $15 \pm 3 \mathrm{~N} / \mathrm{mm}^{2} / \mathrm{min}$ until no greater load can be sustained by the specimen or delamination occurs. The maximum load applied to the specimen was noted. The apparent compressive strength of individual specimen was calculated by dividing the maximum load by the plan area. The corrected compressive strength was then calculated by multiplying the apparent compressive strength by the appropriate correction factor. The flexural strength or breaking load of the paver blocks was determined by applying load from the top of the specimen in the form of a simple beam loading through a roller placed midway between the supporting rollers, as shown in Fig.4. The load was applied without shock and increased continuously at a uniform rate of $6 \mathrm{kN} / \mathrm{min}$. The load was increased until the specimen fails, and the maximum load applied was recorded. The maximum load that can be applied in the paver block is reported as the breaking load.For finding the splitting tensile strength, the paver block was placed on the testing machine with the packing pieces on the upper face and the bed face in contact with the bearers. It was ensured that the packing pieces and the axes of the bearers are in line with the splitting section of the specimen. The splitting section has been chosen as shown in Fig.5.The tensile splitting strength of the specimen was then calculated from the failure load and the area of the failure plane of the paver block. The failure load per unit length of the specimen was then calculated by dividing the failure load by mean of two measurements of the failure length, one at the top and one at the bottom of the specimen.

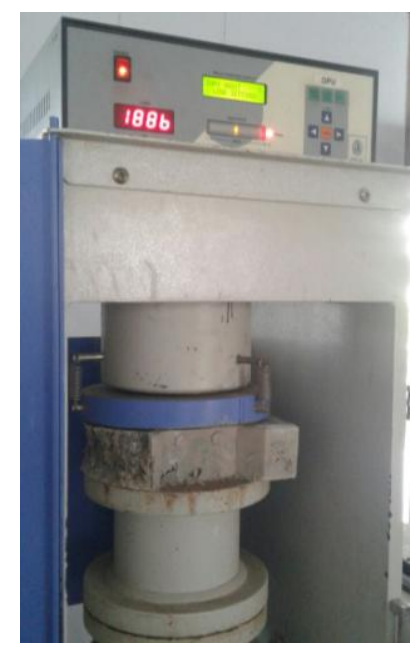

Fig.3. Compression test on Paver block

The abrasion resistance of concrete was found out using specimens of size $71 \mathrm{~mm} \times 71 \mathrm{~mm} \times 60 \mathrm{~mm}$ that are cut from the paver blocks. The contact face and the opposite face of the specimen will be parallel and even. Initially the specimens were dried out to a constant mass at a temperature of $105 \pm 5^{\circ} \mathrm{C}$. The specimen was fixed in the holding device such that the testing surface faces the grinding disc which runs at a speed of $30 \mathrm{rpm}$. The specimen will be centrally loaded with $294+3 \mathrm{~N}$. In the abrasion testing machine, the grinding path of the disc of will be evenly sprinkled with $20 \mathrm{~g}$ of the standard abrasive powder. The disc will be stopped after one cycle of 22 revolutions. The disc and contact face of the specimen will be cleaned of abrasive powder and remains. The specimen will be turned $90^{\circ}$ in the clockwise direction and $20 \mathrm{~g}$ of abrasive powder will be evenly spread on the testing track before proceeding to the next cycle. The test cycle will be repeated 16 times and the abrasive wear of the specimen after 16 cycles of testing will be calculated as the mean loss in specimen volume. 


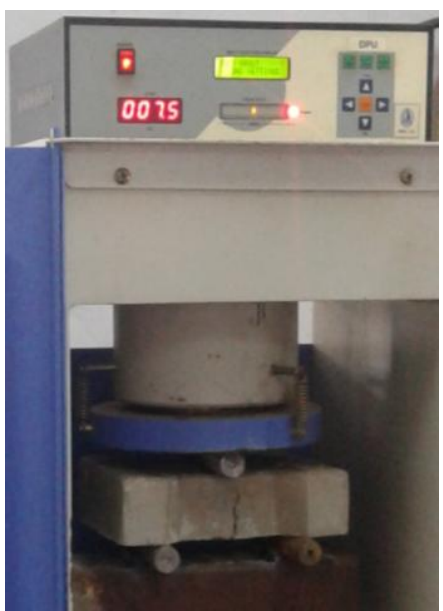

Fig.4. Test set up for flexural strength

For water absorption test, the test specimen shall be completely immersed in water at room temperature for $24 \pm 2$ hours. The specimen then will be removed from the water and allowed to drain for 1 minute by placing them on a $10 \mathrm{~mm}$ or coarser wire -mesh. Visible water on the specimens will be removed with a damp cloth. The specimen shall be immediately weighed and the weight for each specimen was noted. Following the saturation, the specimens will be dried in an oven at $107 \pm 7^{\circ} \mathrm{C}$ for not less than 24 hours and until two consecutive weighing at intervals of 2 hours show an increment of loss not greater than 0.2 percent of the previously determined mass of the specimen. The dry weight of each specimen will then be recorded. The percent water absorption will be calculated from the difference in weight noted due to saturation and subsequent drying of the paver block.

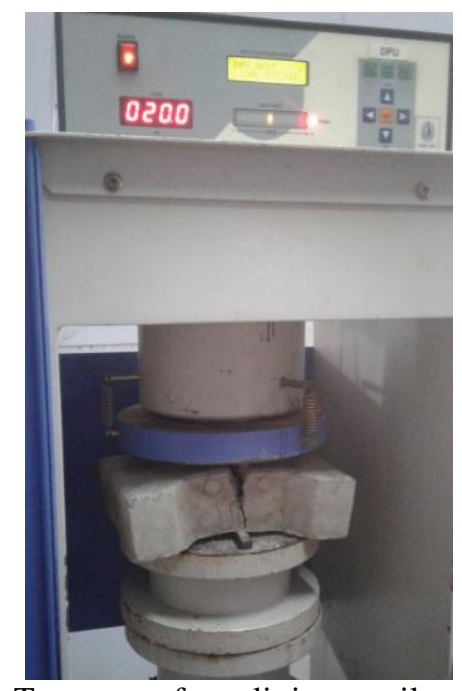

Fig.5. Test set up for splitting tensile strength

\subsection{Density}

\section{Results And Discussion}

The density values of the individual samples and the average density results are given in Table 4.From the density values, it can be seen that the average density is $2414 \mathrm{~kg} / \mathrm{m}^{3}$ which is greater than $2200 \mathrm{~kg} / \mathrm{m}^{3}$ which is the minimum limit specified by the Delhi Development authority for interlocking concrete block pavements.

Table 4: Density

\begin{tabular}{|l|l|l|l|}
\hline Specimen No. & Weight in $\mathbf{~ g}$ & Volume in $\mathbf{~ m}^{\mathbf{3}}$ & Density in $\mathbf{~ k g} / \mathbf{m}^{\mathbf{3}}$ \\
\hline 1. & 4.650 & 0.001879 & 2474.721 \\
\hline 2. & 4.450 & 0.001879 & 2368.281 \\
\hline 3. & 4.620 & 0.001879 & 2458.755 \\
\hline 4. & 4.550 & 0.001879 & 2421.501 \\
\hline 5. & 4.415 & 0.001879 & 2349.654 \\
\hline Average & & 2414.582 \\
\hline
\end{tabular}




\subsection{Compressive Strength}

As per IS 15658: 2006, four paver blocks were tested for compressive strength and the average of compressive strength of four specimens was estimated. From the test results shown in Table 5, it can be seen that the average compressive strength of the paver blocks is $54.63 \mathrm{~N} / \mathrm{mm}^{2}$ which is almost equal to the specified compressive strength of M50 grade paver blocks. The compressive strength of individual paver block values is not less than 85 percent of the specified compressive strength. With respect to compressive strength, the paver blocks produced can be graded as M50 grade since they satisfy the compressive strength requirements as per IS 15658: 2006. With respect to compressive strength this paver block is suitable heavy traffic applications such as Bus terminals, industrial complexes, mandi houses, roads on expansive soils, factory floors, service stations, industrial pavements, etc. However, the minimum thickness of paver recommended for above mentioned applications is $80 \mathrm{~mm}$. Hence considering both thickness and compressive strength, the paver blocks developed can be used for light and medium traffic applications.

Table 5: Compressive Strength

\begin{tabular}{|c|c|c|c|c|c|}
\hline $\begin{array}{l}\text { Specimen } \\
\text { No. }\end{array}$ & $\begin{array}{l}\text { Plan area in } \\
\mathbf{m m}^{2}\end{array}$ & $\begin{array}{l}\text { Ultimate } \\
\text { load in } \mathrm{kN}\end{array}$ & $\begin{array}{l}\text { Apparent } \\
\text { Compressive } \\
\text { strength in } \mathrm{N} / \mathrm{mm}^{2}\end{array}$ & $\begin{array}{l}\text { Correction factor } \\
\text { for } 60 \mathrm{~mm} \text { thick } \\
\text { paver }\end{array}$ & $\begin{array}{l}\text { Corrected } \\
\text { Compressive } \\
\text { strength in } \mathrm{N} / \mathrm{mm}^{2} \\
\end{array}$ \\
\hline 1. & 31333.3 & 1886 & 60.19 & 1.06 & 63.80 \\
\hline 2. & 31333.3 & 1386 & 44.23 & 1.06 & 46.89 \\
\hline 3. & 31333.3 & 1589 & 50.71 & 1.06 & 53.75 \\
\hline 4. & 31333.3 & 1648 & 52.60 & 1.06 & 55.76 \\
\hline \multicolumn{5}{|l|}{ Average } & 54.63 \\
\hline
\end{tabular}

\subsection{Flexural Strength}

As per IS 15658: 2006, four paver blocks were tested for flexural strength and the average breaking load and the flexural strength of four specimens are given in Table 6. From the test results, it can be seen that the average breaking load of the paver blocks is $6.95 \mathrm{kN}$ and the breaking load of three specimens is greater than or equal to $7 \mathrm{kN}$. Hence it is suggested that the paver block developed using fly ash and GGBS can be used for heavy duty or industrial roads.

Table 6: Flexural Strength

\begin{tabular}{|l|l|l|}
\hline $\begin{array}{l}\text { Specimen } \\
\text { No. }\end{array}$ & $\begin{array}{l}\text { Breaking load in } \\
\text { kN }\end{array}$ & $\begin{array}{l}\text { Flexural strength in } \\
\mathbf{N} / \mathbf{m m}^{2}\end{array}$ \\
\hline 1. & 6.3 & 3.137 \\
\hline 2. & 7.0 & 3.485 \\
\hline 3. & 7.0 & 3.734 \\
\hline 4. & 7.5 & 3.734 \\
\hline Average & $\mathbf{6 . 9 5}$ & $\mathbf{3 . 5 2 3}$ \\
\hline
\end{tabular}

\subsection{Splitting Tensile Strength}

Four samples were tested for evaluating the splitting tensile strength. For each of the samples tested, splitting tensile strength and failure load per unit length of the specimen were calculated and the results are given in Table 7.As expected, the splitting tensile strength of paver block specimens is comparatively lesser than that of flexural strength.

Table 7: Splitting Tensile Strength

\begin{tabular}{|l|l|l|l|l|l|}
\hline $\begin{array}{l}\text { Specimen } \\
\text { No. }\end{array}$ & $\begin{array}{l}\text { Failure } \\
\text { load in } \mathbf{~ k N}\end{array}$ & $\begin{array}{l}\text { Failure } \\
\text { length in } \mathbf{~ m m}\end{array}$ & $\begin{array}{l}\text { Thickness at the } \\
\text { failure plane in } \mathbf{~ m m}\end{array}$ & $\begin{array}{l}\text { Split tensile } \\
\text { strength in } \mathbf{~} / \mathbf{m m}^{2}\end{array}$ & $\begin{array}{l}\text { Failure load per unit } \\
\text { length in } \mathbf{~} / \mathbf{m m}^{\mathbf{m}}\end{array}$ \\
\hline 1. & 14.2 & 125 & 62.33 & 1.028 & 113.6 \\
\hline 2. & 11.5 & 122 & 63.33 & 0.845 & 94.26 \\
\hline 3. & 16.8 & 123 & 62.00 & 1.238 & 136.59 \\
\hline 4. & 125 & 65.00 & 1.416 & 160.0 \\
\hline Average & $\mathbf{1 . 1 3 2}$ & $\mathbf{1 2 6 . 1 1}$ \\
\hline
\end{tabular}

\subsection{Water absorption}

The water absorption results of individual paver block samples and the average water absorption value are given in Table 8. From the test results, the average water absorption is $4.89 \%$ which is less than 6 percent by mass, the maximum value specified as per IS 15658: 2006. From the results, individual paver blocks absorbs water less than $7 \%$ which is the limit given in IS 15658: 2006. Hence the paver blocks are suitable for practical applications 
Table 8: Water absorption

\begin{tabular}{|l|l|l|l|}
\hline $\begin{array}{l}\text { Specimen } \\
\text { No. }\end{array}$ & Wet weight in N & Dry weight in N & Water absorption in \% \\
\hline 1. & 45.7 & 43.5 & 5.06 \\
\hline 2. & 42.5 & 40.6 & 4.68 \\
\hline 3. & 44.5 & 42.4 & 4.95 \\
\hline Average & $\mathbf{4 . 8 9}$ \\
\hline
\end{tabular}

\subsection{Abrasion resistance}

The abrasion wear test was conducted as per the procedure given in IS 15658: 2006 and the loss in volume and thickness of the specimens were calculated and the results are given in Table 9. The average loss in thickness is $3.17 \mathrm{~mm}$ which is less than the limiting maximum value of $3.5 \mathrm{~mm}$ prescribed for general purpose paver blocks. Hence the paver blocks can be used for general purpose applications.

Table 9: Abrasion Resistance

\begin{tabular}{|c|c|c|c|c|c|c|}
\hline $\begin{array}{l}\text { Specimen } \\
\text { No. }\end{array}$ & Size in $\mathbf{m m}$ & $\begin{array}{l}\text { Initial weight } W_{1} \\
\text { in } \mathrm{kg}\end{array}$ & $\begin{array}{lr}\text { Weight } & \text { after } \\
\text { abrasion } & W_{2} \text { in } \\
\text { kg } & \end{array}$ & $\begin{array}{l}\text { Density in } \\
\mathrm{kg} / \mathrm{m}^{3}\end{array}$ & $\begin{array}{l}\text { Loss in Volume } \\
\text { in } \mathrm{m}^{3}=\text { Weight } \\
\text { loss } / \text { Density }\end{array}$ & $\begin{array}{l}\text { Loss in } \\
\text { Thickness } \\
\text { in mm } \\
\end{array}$ \\
\hline 1. & $71 \times 71 \times 60$ & 0.861 & 0.815 & 2846 & $1.616 \times 10^{-5}$ & 3.2 \\
\hline 2. & $71 \times 71 \times 60$ & 0.857 & 0.812 & 2831 & $1.589 \times 10^{-5}$ & 3.15 \\
\hline 3. & $71 \times 71 \times 60$ & 0.872 & 0.825 & 2855 & $1.646 \times 10^{-5}$ & 3.27 \\
\hline 4. & $71 \times 71 \times 60$ & 0.862 & 0.818 & 2847 & $1.545 \times 10^{-5}$ & 3.06 \\
\hline \multicolumn{5}{|l|}{ Average } & $1.599 \times 10^{-5}$ & 3.17 \\
\hline
\end{tabular}

\section{Conclusion}

Based on the experimental investigations carried out the following conclusions are arrived at:

- Based on compressive strength attained in this study, the paver blocks developed can be used for light and medium traffic applications

- From the flexural strength point of view, paver blocks developed using fly ash and GGBS can be used for heavy duty or industrial roads.

- The individual paver blocks absorbs water less than $7 \%$ and the average water absorption is less than $6 \%$ which makes them suitable for practical applications.

- Due to abrasion wear, the average loss in thickness is $3.17 \mathrm{~mm}$ which is less than the limiting maximum value of $3.5 \mathrm{~mm}$ prescribed for general purpose paver blocks. Hence the paver blocks can be used for general purpose applications.

The objective of this paper is to develop paver blocks without cement using geopolymer technology. These paver blocks are greener since the emission of carbon dioxide is prevented. By the application of geopolymer technique the problem disposal of fly ash can be solved to a certain extent.

\section{Acknowledgement}

The authors sincerely thank University Grants Commission (UGC), New Delhi for funding this project to Dr.R.Kumutha as the Principal Investigator under Minor Research projects scheme.

\section{References}

[1] Ling, T. C., Nor, H. M., Hainin, M. R., and Lim, S. K., "Long Term Strength of Rubberized Concrete Paving Blocks", ICEConstruction Materials Conference, 2010,19-26.

[2] Aaron Darius Vaz., Donal Nixon D'Souza., NoothanKaliveer.,Satish, K. T., Amar, S. M., "Geopolymer Paver Blocks" International Conference on Advances in Civil Engineering, 2012.

[3] Basil Mali, M. and Renjan Abraham., "Study on geopolymer concrete used for paving blocks", International Journal of Innovative Research in Advanced Engineering, 3 (9), 2016, $62-66$.

[4] Navya,G and Venkateeswara Rao.J, "Influence of Polyester fibre on Concrete Paver Blocks", IOSR Journal of Mechanical and Civil Engineering (IOSR- JMCE), 11(4), 2014, 70-75.

[5] Banupriya, C., Sharon John, Suresh, R., Divya, E., Vinitha, D., "Experimental investigations on geopolymer bricks / paver blocks", Indian Journal of Science and Technology, 9 (16), 2016.

[6] Vijai, K., Kumutha, R., Vishnuram, B. G., "Effect of types of curing on strength of geopolymer concrete", International Journal of Physical Sciences, 5(9), 2010,1419-1423.

[7] Girawale, M. S., "Effect's of alkaline solution on geopolymer concrete", International Journal of Engineering Research and General Science, 3 (4), 2015

[8] Srinivas, K. S., Prathap Kumar, M. T., Prema Kumar, W. P., "Comparative performance of geopolymer concrete exposed to acidic environment", International Journal of Research in Engineering and Technology, 4 (4) ,2015

[9] Indian Standard 15658:2006 Precast Concrete Blocks For Paving, Bureau of Indian Standards, New Delhi 